\title{
Morphology of three Brazilian species of Semiotus (Coleoptera, Elateridae, Semiotinae)
}

\author{
Maria Helena Parreira ${ }^{1}$ \& Sônia A. Casari ${ }^{1,2}$
}

1. Museu de Zoologia, Universidade de São Paulo, Caixa Postal 42494, 04218-970, São Paulo, SP, Brasil. (casari@usp.br)
2. Fellowship CNPq.

\begin{abstract}
The morphology of Semiotus distinctus (Herbst, 1806), S. intermedius (Herbst, 1806) and S. ligneus (Linnaeus, 1767), including mouthparts and male and female genitalia, is described and illustrated. A comparative analysis of the characters related to the external morphology, mouthparts and male and female genitalia is also included.
\end{abstract}

KEYWORDS. Elateridae, genitalia, morphology, mouthparts, Semiotus.

\section{INTRODUCTION}

The genus Semiotus was established by EschschOLTZ (1829) to include four species from Elater: E. lignarius Fabricius, 1792, E. distinctus Herbst, 1806, E. intermedius Herbst, 1806, and E. furcatus Fabricius, 1792. Castelnau (1840) redescribed this genus, including it in "Tetralobites", together with Tetralobus Lepeletier \& Serville, 1825, Allotrius Castelnau, 1840, Eschscholtzia Castelnau, 1840, Pomachilius Eschscholtz, 1829, Conoderus Eschscholtz, 1829, Monocrepidius Eschscholtz, 1829 and Synaptus Eschscholtz, 1829, characterized by tarsi lamellate. At that time, Semiotus was formed by four species: $S$. distinctus (Herbst), S. furcatus (Fabricius), $S$. intermedius (Herbst) and S. suturalis (Fabricius, 1792). CANDĖZE (1857) included Semiotus in "Chalcolepidiites", together with Chalcolepidius Eschscholtz, 1829, Campsosternus Latreille, 1834 and Oistus Candèze, 1857, sharing the meso- and metasternum fused behind the mesosternal cavity. At moment, Chalcolepidius was transferred to Hemirhipini, Campsosternus to Oxynopterini and Semiotus and Oistus to Semiotinae. LACORDAIRE (1857) followed CANDÈzE (1857) and kept Semiotus in "Chalcolepidiites". CANDĖZe (1874) decribed 13 new species. CANDÈZE (1891) catalogued 80 species to this genus, separated into 7 groups according to coloration pattern, presence of spines and shape of frons and presence of spines and shape of elytral apices. BLACKWELDER (1944) catalogued 90 species to this genus, recorded from Mexico to Bolivia.

The genus Semiotus includes large sized and colorful beetles (14-48 mm), with very bright integument. The coloration is usually yellow with longitudinal stripes black, orange or reddish. Since now, it has been characterized especially by antennae 11segmented and serrate; mandibles toothed; tarsal segments 1-2 lamellate beneath; each elytron with one or two distal spines; last ventrite entire with rounded apex in both sexes and bearing, in female, two fossae clothed with short setae. The mouthparts and genitalia male and female had not been studied.
Herein, the morphology of three species, very common in Brazil, are described and illustrated.

\section{MATERIAL AND METHODS}

The material studied belongs to the collection of Museu de Zoologia, Universidade de São Paulo (MZSP). Were analyzed 237 specimens of S. distinctus, 542 of $S$. intermedius and 171 of S. ligneus Linnaeus, 1767. For dissections and preparation of male genitalia and hind wing it was followed CALDER (1996), for female genitalia, BECKER (1956) and mouthparts CASARI-CHEN (1993), with some variations. The nomenclature follows CASARI-CHEN (1994), CALDER (1996) and CALDER et al. (1993).

For illustrations, the mouthparts, genitalia and genital segments of male and female were temporarily mounted in glycerin on a slide and drawn with the aid of a camera lucida attached to a stereomicroscope.

\section{Semiotus distinctus (Herbst, 1806)}

(Figs. 1, 4-26)

Elater distinctus HeRBST, 1806:5.

Semiotus distinctus; Eschscholtz, 1829:31; Germar, 1839:210; Castelnau, 1840:231; Candèze, 1857:301; Heyne \& TaschenberG, 1908:154; SCHENKLING, 1925:61 (cat.); BLACKWELDER, 1944:284. Elater inermis KIRBY, 1818:383.

Redescription. Length: $28-48 \mathrm{~mm}$. Bright, coloration from reddish-yellow to ferrugineous with longitudinal stripes on pronotum and elytra from reddish-brown to black (fig. 1). Antennae dark-brown or brown with three first articles brownish or yellowish. Pronotum with one longitudinal median stripe not reaching base. Scutellum marginated by dark-brown band. Elytra with two stripes: one sutural two insterstices wide, except anterior half narrower, only on 1 st interstice; second stripe on 5th and 6th interstices, almost reaching apices. Prosternum, in some specimens, with narrow longitudinal median darker band. Pubescence thin and sparse, yellowish or brownish, longer ventrally.

Frons narrow, rectangular, strongly grooved at middle, forming a triangular concavity; fore angles rounded; punctation sparser than pronotum. Antennae 
(fig. 4): in males surpassing hind angles of pronotum in two articles; in females almost reaching them; 11-segmented and serrate from 3rd segment, stronger in males; segments elongate. Labrum (fig. 5) transverse, semicircular, marginate by irregular fringe of long setae. Epipharynx (fig. 6) membranous, densely clothed with thin and clear setae; sensorial pores near middle, some in groups. Mandibles (figs. 11, 12) symmetrical, narrow, with apex curved and one subapical tooth; dorsally raised, with a median carina and setae of varied sizes near lateral margin; penicillum formed by fringe of short and thin setae. Maxillae (fig. 7): cardo subtriangular, projected distally, with moderately long setae near base; basistipes subtriangular bearing long setae near middle and mediostipes punctuate; galea and lacinia brushlike, densely clothed with short setae. Palpifer sclerotized and setous near base; maxillary palpi 4-segmented and setous; basal segment transverse and distal elongate with apex strongly securiform. Labium (fig. 8): mentum membranous on anterior half, bearing long setae on basal sclerotized half; ligula marginate by fringe of short setae with a group of long setae near middle. Palpigers separate, each bearing 5 moderately long setae; labial palpi 3-segmented and setous; distal segment strongly securiform. Hypopharynx (fig. 9) clothed totally with thin, yellowish and moderately long setae. Pronotum rectangular, slightly widened basad, convex, slightly grooved near lateral margins; anterior margin sinuous, slightly prominent and raised near middle; fore angles prominent, flat and rounded; hind angles very prominent backward, slightly divergent and raised laterally; punctuation small longitudinal-medially and coarse and dense laterally; median basal tubercle prominent and rounded. Prosternum convex with punctuation coarse, dense and heterogeneous. Prosternal lobe with fore angles slightly rounded, punctation smaller and sparser than prosternum. Prosternal spine (fig. 10) flattened laterally, with bilobed apex. Hypomera slightly concave with punctuation coarse, heterogeneous and dense; lateral margins raised and smooth. Notosternal sutures slightly curved. Mesosternal cavity U-shaped with borders horizontal at base and strongly declivous distally. Mesosternum (fig. 10) fused to metasternum behind mesosternal cavity. Scutellum (fig. 14) semi-elliptical, declivous anteriorly, slightly concave at middle; lateral margins slightly raised. Elytra gradually narrowed apicad, each with one sharpened apical spine; striae formed by row of coarse punctures; interstices flat. Legs: tibial spurs present; three first tarsal articles lamellate beneath. Hind wing (fig. 13) with edge cell (w) present. Last ventrite with rounded apex in both sexes; in females (fig. 22) with two elliptical fossae clothed with short and thin setae.

Genital segments of male and aedeagus. Sternite 8 (fig. 16) transverse with anterior margin strongly notched at middle, making fore angles very prominent; fringe of moderately long setae anterior and parallel lateral margins. Tergite 8 (fig. 15) elongate, slightly narrowed apicad, translucent at median basal region, clothed with microsetae, with longer setae near margins of distal half. Tergite 9 (fig. 21) transverse, punctate, anterior margin strongly notched at middle, fore angles rounded, sparsely punctuate, with short setae laterally; tergite 10 reduced, densely punctuate and marginate by fringe of short setae. Sternite 9 (fig. 17) elongate, with short setae on distal third. Aedeagus (figs. 18, 19): median lobe (fig. 20) narrow, longer than parameres, bearing ventrally a membrane and a narrow elongate sclerite near base; parameres separated, almost straight, with subapical lateral unciform tooth, making subapical region securiform with short setae. Basal piece slightly wider than parameres.

Genital segments of female and genitalia. Tergite 8 (fig. 25) triangular, translucent mediobasally, densely punctuated with short setae at apex. Sternite 8 (fig. 26) elliptical, clothed with short setae; longer setae near margin; spiculum gastrale very long, four times sternite length. Genitalia: ovipositor (fig. 23) with stylus; baculum 6.2 times coxites length; each opening of colleterial gland (fig. 24) with one sclerotized wingshaped plate, with 7 rows of teeth innerly; bursa copulatrix bearing small spines at median third; two spermathecae distally.

Material examined. BRAZIL, Amazonas: "Estrada para Manaus”, $\Varangle ;$ Bahia: Soure, $\subsetneq$; Minas Gerais: Pouso Alegre, $\mho^{\prime}$; Espírito Santo: Linhares, 3 \&, 5 \&; (Parque Sooretama), 2 \&; Santa Tereza,, ; Rio de Janeiro: Angra dos Reis, $\widetilde{\sigma}$; Rio de Janeiro (Corcovado),

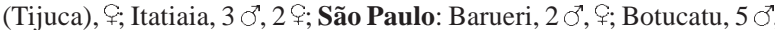
$3 \subsetneq$; Campos do Jordão, ơ; Cantareira, $\subsetneq$; Itu (Fazenda Pau d'Alho), $\widetilde{\sigma}$ Marília, 4 \&; Monte Alegre, ơ; Pindamonhangaba, 31 \&; Porto Cabral, ‡; Regente Feijó, 2 ‡; Rio Claro, ơ; Rio Preto, q; Salesópolis (Estação Biológica de Boracéia), §; São Sebastião, 2 ; Ubatuba, 2 ; Paraná:

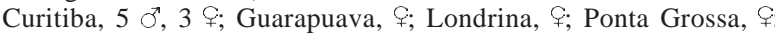

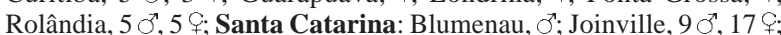

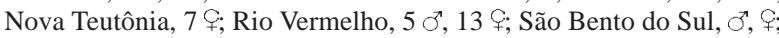
Timbó, 8 ơ, 59 ६; Rio Grande do Sul: Salvador do Sul, ơ.

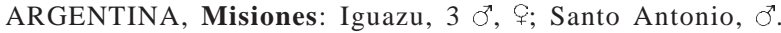
PARAGUAY, o

\section{Semiotus intermedius (Herbst, 1806)}

(Figs. 2, 27-45)

Elater intermedius HERBST, 1806:8.

Semiotus intermedius; Eschscholtz, 1829:31; CAstelnau, 1840:231; CANDÈZE, 1857:301; SCHENKLING, 1925:62 (cat.); Blackwelder, 1944:284 (cat.).

Elater cornutus KIRBY, 1818:383.

Semiotus cornutus; GERMAR, 1839:210.

Redescription. Length: 14-40 mm. Bright, coloration from yellow to reddish-yellow with longitudinal stripes on pronotum and elytra from ferrugineous to dark-brown (fig. 2). Antennae black or dark-brown with two first articles brownish or yellowish. Median region of pronotum reddish with two longitudinal irregular elliptical stripes, not reaching anterior margin; each side with one dark rounded patch on anterior third. Scutellum marginated by dark-brown band. Elytra with two stripes: one sutural two insterstriae wide, except anterior third narrower, only on sutural; lateral stripe, at base from 6th interstice to margin, narrowed apicad, finishing only on 2 nd, not reaching apices. Hypomera with narrow longitudinal darker stripe near lateral margins. One longitudinal darker stripe on each side of ventrites. Pubescence thin and sparse, yellowish or brownish, longer ventrally.

Frons narrow, rectangular, strongly grooved at middle, forming a triangular concavity; each fore angle 

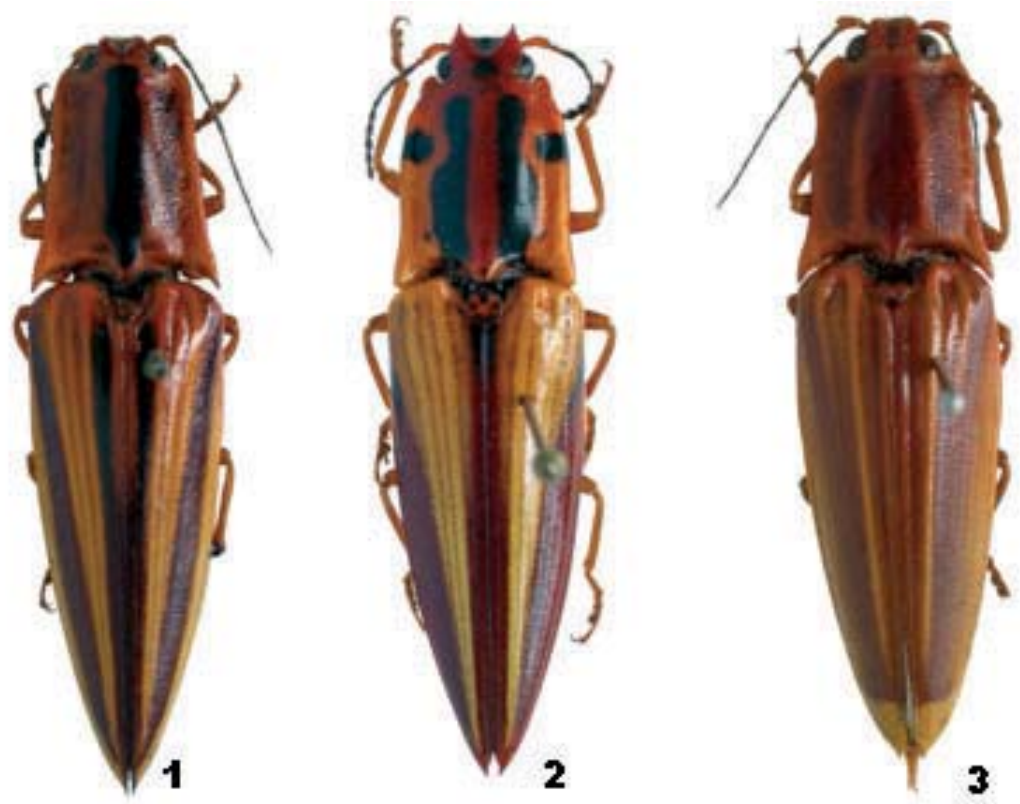

Figs.1-3. Habitus: 1, Semiotus distinctus (Herbst, 1806); 2, Semiotus intermedius (Herbst, 1806); 3, Semiotus ligneus (Linnaeus, 1767). Length, respectively, $35,27,31 \mathrm{~mm}$.

bearing a tooth; punctation sparser than pronotum. Antennae (fig. 27) short, not reaching hind angles of pronotum; 11-segmented and slightly serrate from 3rd article, with longitudinal smooth raised band from 3rd segment. Labrum (fig. 28) tranverse, sub-rectangular, with fore angles rounded; sparse and long setae on anterior half. Epipharynx membranous, densely clothed with thin and clear setae and sensorial pores near middle. Mandibles (figs. 30, 31) symmetrical, narrow, with apex curved and a subapical tooth; dorsally raised, with a median carina and moderately long setae near lateral margin; penicillum formed by dense fringe of long and thin setae. Maxillae (fig. 29): cardo subtriangular, projected distally, with moderately long setae near base; basistipes with short setae and mediostipes punctuate; galea and lacinia brush-like, densely clothed with short setae. Palpifer sclerotized and setous near base; maxillary palpi 4-segmented and setous; basal segment transverse and distal elongate with securiform apex. Labium (fig. 32): mentum membranous on anterior half, bearing long setae on basal sclerotized half; ligula marginated by fringe of short setae. Palpiger separate bearing 5 long setae; labial palpi 3-segmented and setous; distal segment securiform. Gula with transverse row of moderately long setae near apex and near base. Hypopharynx totally clothed with thin, yellowish and moderately long setae. Pronotum rectangular strongly widened at base, convex and slightly grooved near lateral margins; anterior margin almost straight with a concavity near fore angles; fore angles prominent and rounded; hind angles divergent, slightly raised laterally; punctuation dense and coarse; median basal tubercle rounded. Prosternum convex with punctuation coarse, dense and heterogeneous. Prosternal lobe with fore angles slightly rounded, with punctation smaller and sparser than prosternum. Prosternal spine (fig. 33) compressed laterally, with rounded apex. Hypomera slightly concave with punctuation coarse, heterogeneous and dense; lateral margins raised and smooth. Notosternal sutures slightly curved. Mesosternal cavity (fig. 33) Ushaped with borders wide and horizontal at base and strongly declivous at anterior half. Mesosternum fused to metasternum behind mesosternal cavity. Scutellum subquadrangular and concave at middle; anterior margin notched and posterior rounded at middle. Elytra gradually narrowed apicad, each with one sharpened apical tooth; subapical region slightly notched innerly; striae marked by row of weak and moderately coarse punctures; interstices flat. Legs: tibial spurs present; three first tarsal articles lamellate beneath. Hind wing with edge cell (w) present. Last ventrite slightly with apex rounded in male and truncate in female; females (fig. 40) with two elliptical fossae clothed with short and thin setae.

Genital segments of male and aedeagus. Sternite 8 (fig. 37) transverse, with anterior margin widely notched at middle and fore angles strongly prominent; short setae near distal half, longer at fore angles. Tergite 8 (fig. 36) subtriangular, translucent at median basal region, clothed with microsetae and with longer setae near margins of distal third. Tergite 9 (fig. 34) transverse, narrowed apicad; anterior margin strongly notched at middle, fore angles rounded; sparsely punctuated with moderately long setae laterally on distal third; tergite 10 reduced, punctuate and marginate anteriorly by fringe of moderately long setae. Sternite 9 (fig. 35) elongate with short setae on distal third. Aedeagus (figs. 38, 39): median lobe narrow, almost as long as parameres; parameres separated, almost straight, each with well developed subapical almost straight lateral tooth; short setae near apex. Basal piece long, almost as wide as parameres.

Genital segments of female and genitalia. Tergite 8 (fig. 41) triangular, translucent mediobasally, clothed with short setae; moderately long setae laterally near apex. Sternite 8 (fig. 45) elliptical, clothed with short setae; longer setae near margin; spiculum gastrale very long, 4.7 times sternite length. Genitalia (fig. 44): ovipositor 


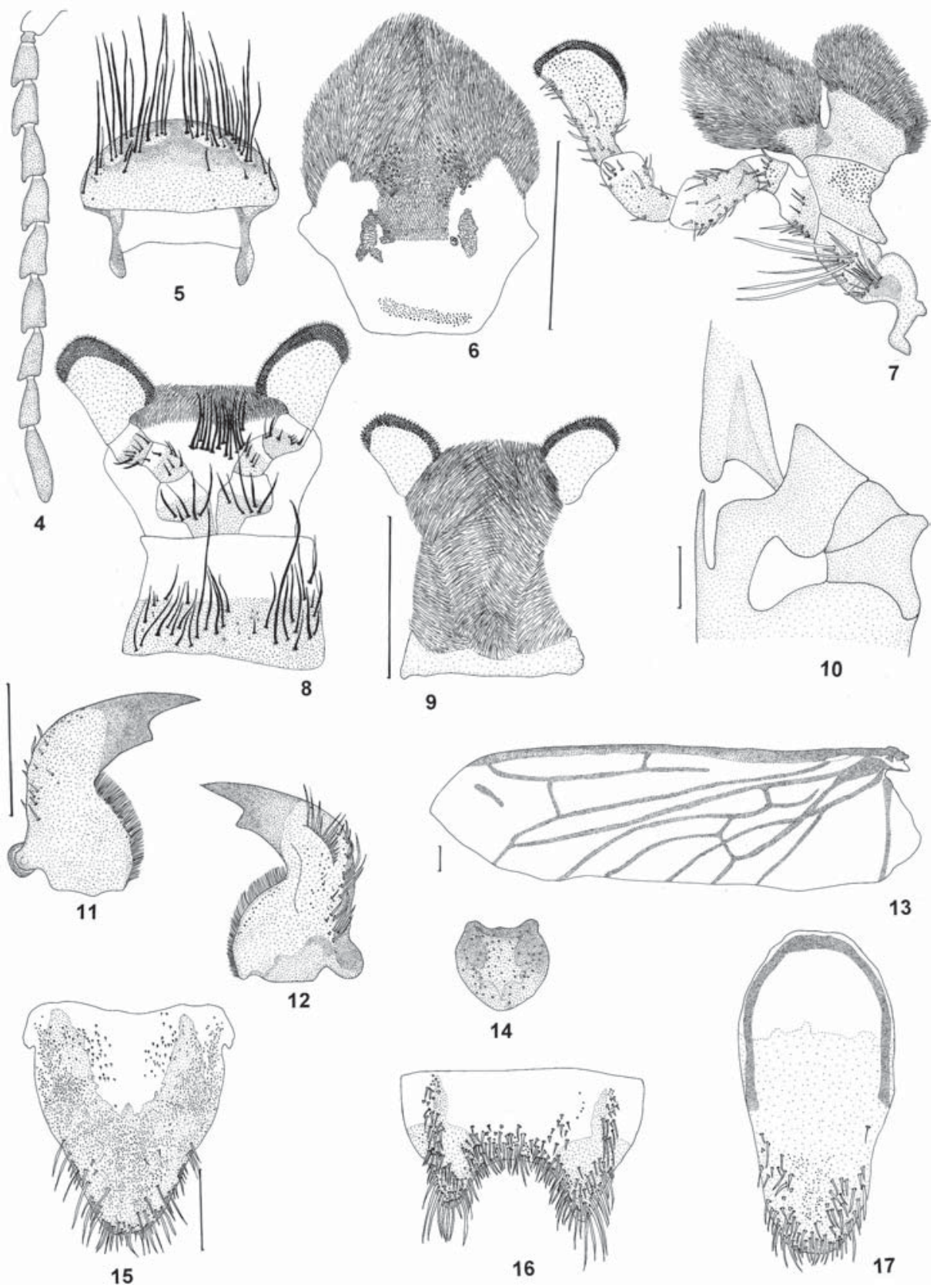

Figs. 4-17. Semiotus distinctus: 4, antenna; 5, labrum; 6, epipharynx; 7, maxilla; 8, labium; 9, hypopharynx; 10; apex of prosternal spine and mesosternum (lateral); 11, 12, mandible (ventral, dorsal); 13, hind wing; 14, scutellum. Male: 15, tergite 8; 16, sternite 8; 17, sternite 9 . Bars $=1 \mathrm{~mm}$.

with stylus; bacula 7.3 times coxites lengh; each opening of colleterial gland (fig. 43) with one sclerotized wingshaped plate, with 7 rows of teeth innerly; bursa copulatrix spiny innerly with sclerotized plate anchorlike (fig. 42); two spermathecae distally.

Material examined. BRAZIL, Amazonas: Benjamin Constant (Rio Javari), 2 ; Goiás: 5 ‡; Mato Grosso: 4 ; Minas Gerais: Lavras, 2 ; Passos, $\varsubsetneqq$; Poços de Caldas, đ, 3 ; ; Pouso Alegre, 3 ; Serra da Mantiqueira, $\varsubsetneqq$; Vila Monte Verde, 19 \&; Espírito Santo: Linhares (Parque Sooretama), \&; Rio de Janeiro: Rio de Janeiro (Jacarepaguá), ₹; (Corcovado), ơ; Itatiaia, ơ, 4 §; (Parque Nacional),

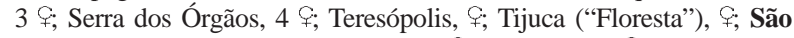
Paulo: Anhembi (Faz. Bar. Ricco), ६; Bocaina, 4 ६; Campos do Jordão, ơ; Cantareira, ơ, 3 ;; Ilha de São Sebastião, \&; Monte Alegre (Faz. Santa Maria), 2 ; Pindamonhangaba, ఢ̨; Salesópolis (Estação
Biológica de Boracéia), 4 \&, São Paulo, §; Paraná: Londrina, ơ, 4 \&,

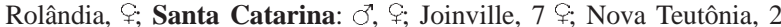
o', 10 §; Rio Natal, 4 ‡; Rio Vermelho, 15 o, 107 ‡; São Bento do Sul, 5 ६; "estr." Santa Catarina, 9 ‡; Timbó, 8 वै, 283 ‡; Rio Grande do Sul: Aratinga (= Santa Teresa), 4 \&.

\section{Semiotus ligneus (Linnaeus, 1767)}

(Figs. 3, 46-62)

Elater ligneus LinNaeus, 1767:652; OlivieR, 1790:17; FABRICIUS, 1801:224.

Elater lignarius FABRICIUS, 1792:219.

Semiotus ligneus; Eschscholtz, 1829:31; CANDĖze, 1857:302; ChAMPION, 1894:291; HEYNe \& TASCHENBERG, 1908:154; SCHENKLING, 1925:62 (cat.); BLACKWELDER, 1944:284 (cat.).

Redescription. Length: 15-44 mm. Bright, 

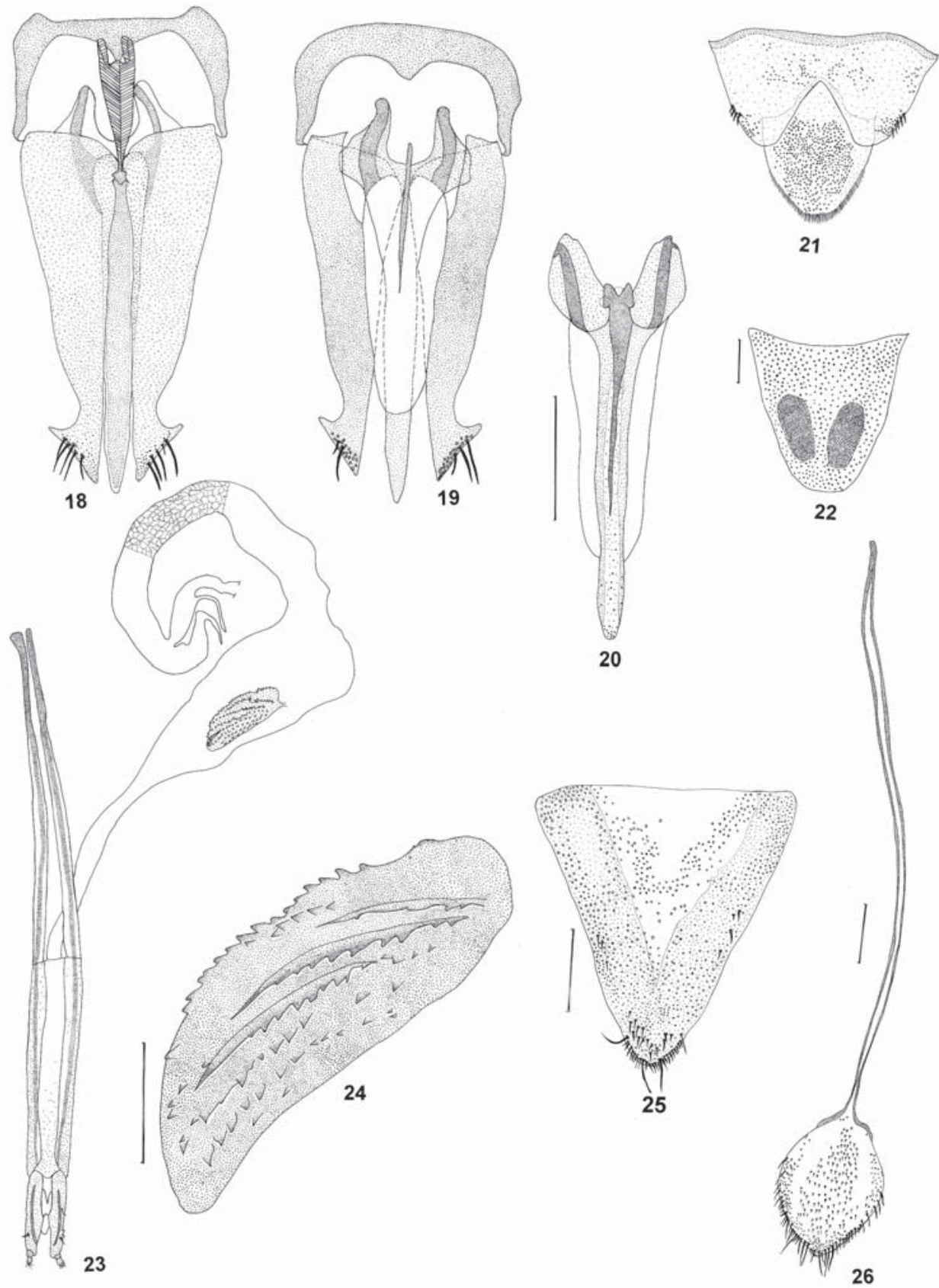

Figs 18-26. Semiotus distinctus. Male: 18, 19, aedeagus (dorsal, ventral); 20, median lobe (ventral); 21, tergites 9-10. Female: 22, last ventrite; 23 , genitalia; 24 , sclerotized piece of opening of colleterial gland; 25 , tergite $8 ; 26$, sternite 8 . Bars, $1 \mathrm{~mm}$, except fig. $24,0.5 \mathrm{~mm}$.

coloration from yellowish-brown to ferrugineous with longitudinal stripes on pronotum and elytra brownish or yellow (fig. 3). Antennae dark-brown or brownish with two first articles brownish or yellow. Pronotum yellow with three wide brownish longitudinal elliptical stripe not reaching margins. Scutellum marginated by brownish band. Elytra brownish with apices yellow; narrow yellow band on 2nd interstice and at lateral margins. Hypomera and sides of ventrites 1-4 with longitudinal brownish patches. Pubescence thin and sparse, yellowish or brownish, longer ventrally.

Frons narrow, rectangular, strongly grooved at middle, forming a triangular concavity; fore angles raised and rounded; punctation sparser and thinner than pronotum. Antennae (fig. 46) surpassing hind angles of pronotum in one article in male; in females almost reaching them; 11-segmented and serrate from 3rd article, stronger in males. Labrum (fig. 47) transverse, semicircular, marginate by irregular fringe of long setae. Epipharynx membranous, densely clothed with thin and clear setae and sensorial pores near middle, some in group. Mandibles (figs. 50, 51) symmetrical, narrow, with apex curved and a subapical tooth; dorsally raised, with a median carina and setae of varied sizes near lateral margin; penicillum formed by fringe of short and thin setae. Maxillae (fig. 49): cardo subtriangular, projected distally, with moderately long basal setae near middle; basistipes bearing long setae near middle and mediostipes punctuate near middle; galea and lacinia brush-like, densely clothed with short setae. Palpifer sclerotized and setous near base; 


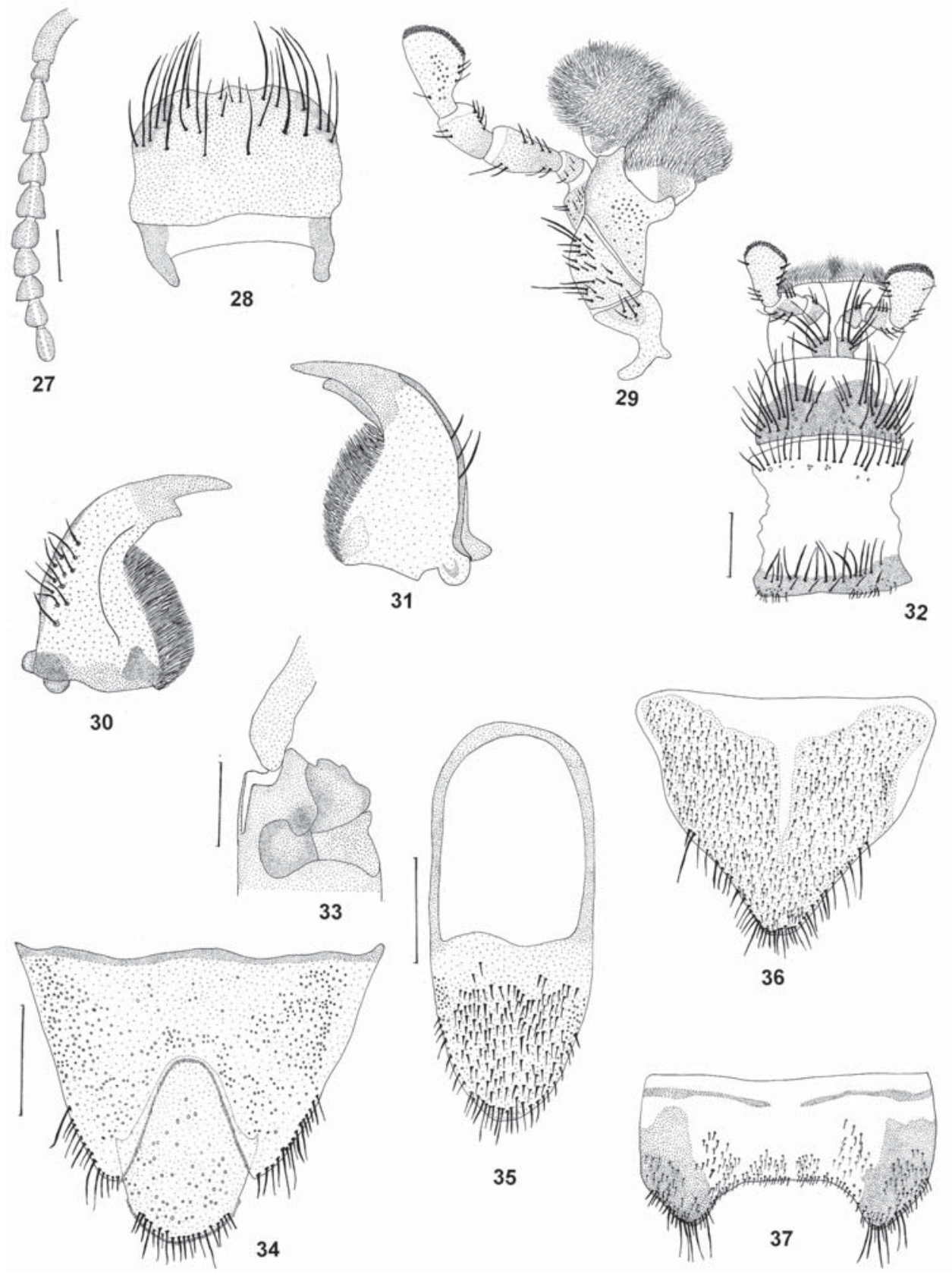

Figs. 27-37. Semiotus intermedius. 27, antenna; 28, labrum; 29, maxilla; 30, 31, mandible (dorsal, ventral); 32, labium; 33, apex of prosternal spine and mesosternum (lateral). Male: 34 , tergites $9-10 ; 35$, sternite $9 ; 36$, tergite $8 ; 37$, sternite 8 . Bars $=1 \mathrm{~mm}$.

maxillary palpi 4-segmented and setous; basal segment transverse and distal elongate with apex strongly securiform. Labium (fig. 52): mentum membranous on anterior half, bearing setae of varied sizes on basal sclerotized half; ligula marginate by fringe of short setae with a group of long setae near middle. Palpiger separate, bearing 4 setae of varied sizes; labial palpi 3-segmented and setous; distal segment strongly securiform. Hypopharynx totally clothed with thin, yellowish and moderately long setae. Pronotum rectangular, slightly widened basad; convex and slightly grooved near lateral margins; anterior margin sinuous, slightly prominent and raised near middle; fore angles prominent, rounded and flat; hind angles very prominent backwards, slightly raised laterally; punctuation small longitudinal- medially and coarse and very dense laterally; median basal tubercle rounded. Prosternum convex with punctuation coarse, dense and heterogeneous. Prosternal lobe with fore angles slightly rounded, with punctation smaller and sparser than prosternum. Prosternal spine (fig. 48) compressed laterally with bilobed apex. Hypomera slightly concave with punctuation coarse, heterogeneous and dense; lateral margins raised and smooth. Notosternal sutures slightly curved. Mesosternal cavity U-shaped with borders (fig. 48) horizontal at base and declivous on distal third. Mesosternum fused to metasternum behind mesosternal cavity. Scutellum cordiform, declivous anteriorly, slightly concave at 


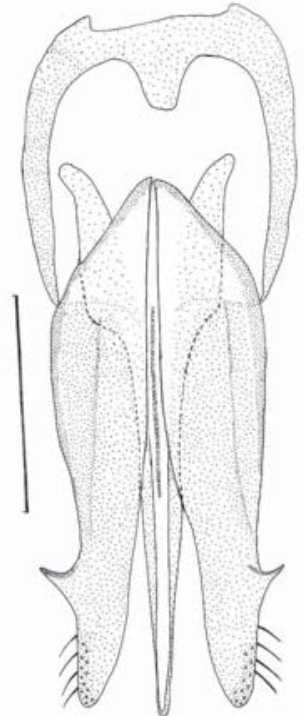

38

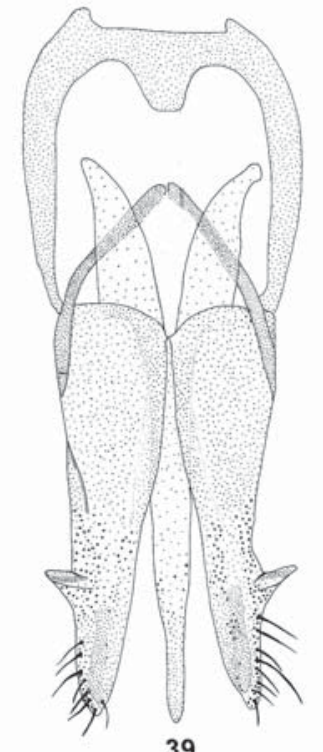

39

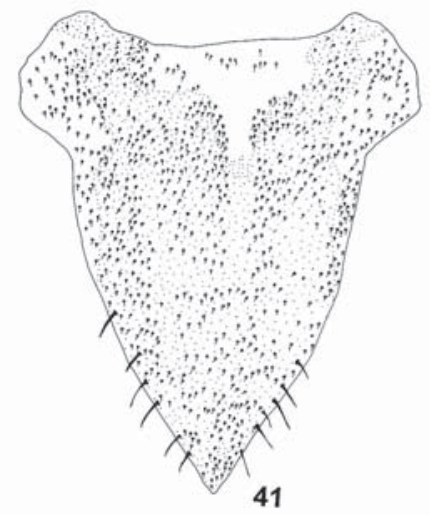

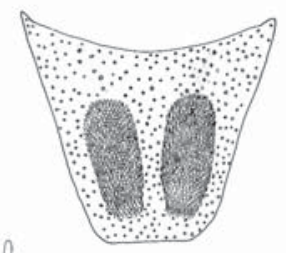

40

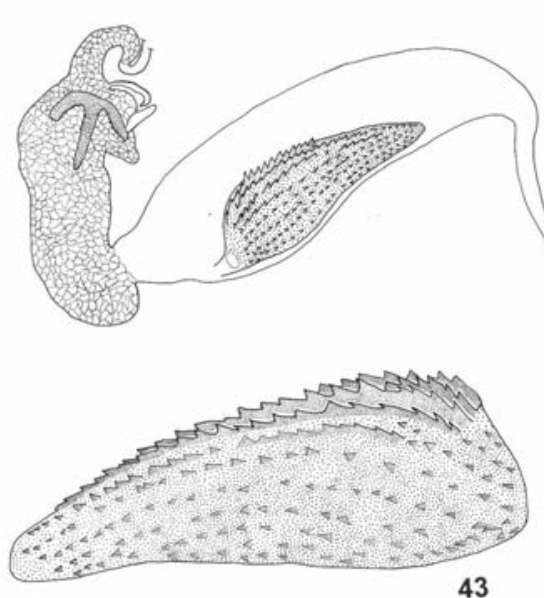

43
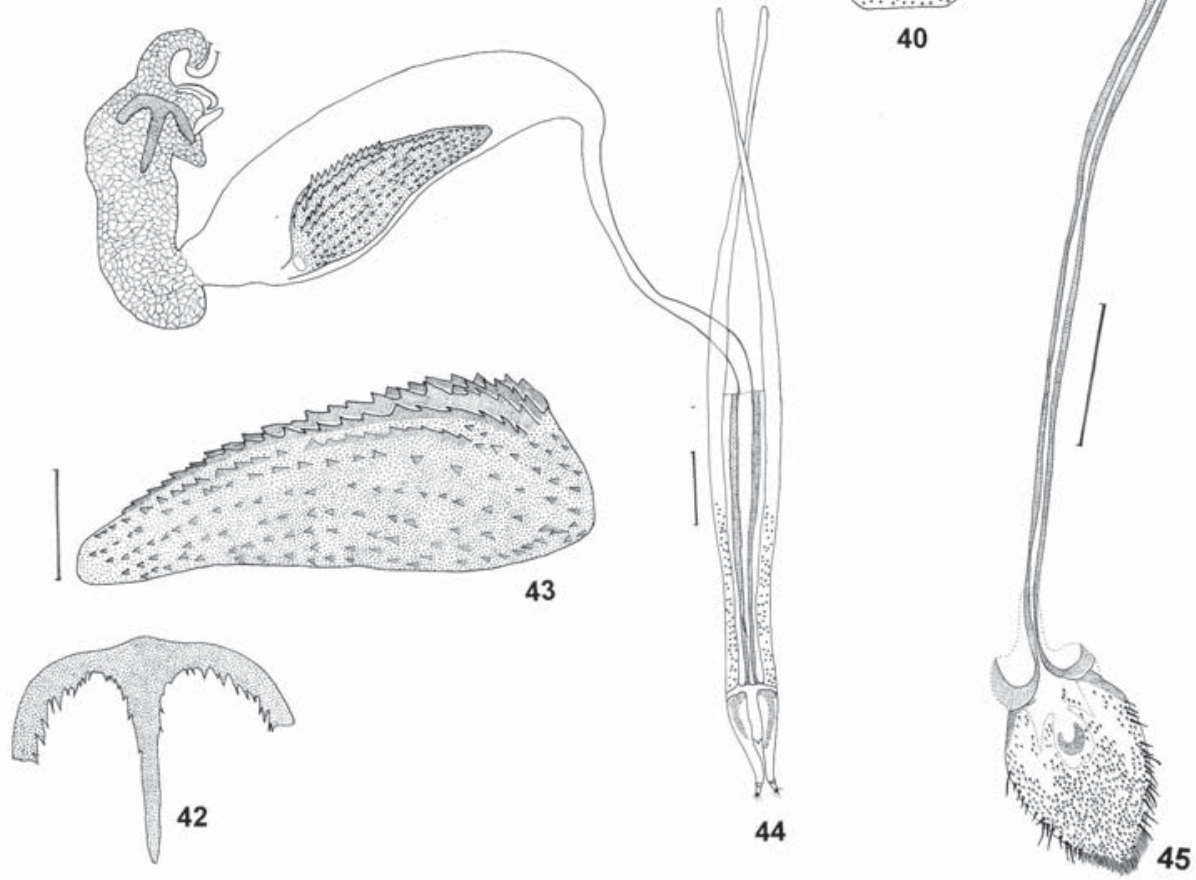

Figs. 38-45. Semiotus intermedius. Male: 38, 39, aedeagus (ventral, dorsal). Female: 40, last ventrite; 41, tergite 8; 42, sclerite of bursa copulatrix; 43, sclerotized piece of opening of colleterial gland; 44, genitalia; 45, sternite 8 . Bars, $1 \mathrm{~mm}$, except figs. $41,42,0.5 \mathrm{~mm}$.

middle, with lateral margins slightly raised. Elytra gradually narrowed apicad, each with one sharpened apical tooth; subapical region notched innerly; striae formed by row of coarse punctures; interstices flat. Legs: tibial spurs present; three first tarsal articles lamellate beneath. Hind wing with edge cell (w) present. Last ventrite with rounded apex in both sexes; females (fig. 62) with two circular fossae clothed with short and thin setae.

Genital segments of male and aedeagus. Sternite 8 (fig. 53) transverse with anterior margin widely notched and fore angles prominent; moderately long setae on distal half. Tergite 8 (fig. 54) triangular, translucent at basal median region, clothed with microsetae and with longer setae near margins of distal third. Tergite 9 (fig. 58) transverse, anterior margin strongly notched at middle, fore angles rounded, sparsely punctuated with long setae laterally on anterior margin; tergite 10 reduced, densely punctuate and marginate by fringe of short setae. Sternite 9 (fig. 55) elongate, with long setae on distal third. Aedeagus (figs. 56, 57): median lobe narrow, longer than parameres; parameres separated, almost straight, with subapical lateral unciform tooth, making subapical region securiform, with short setae. Basal piece wider than parameres.

Genital segments of female and genitalia. Tergite 8 (fig. 60) triangular, punctuate, translucent mediobasally, clothed with short setae; moderately long 


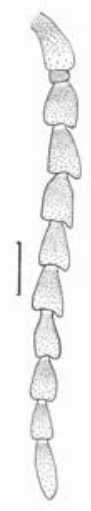

46

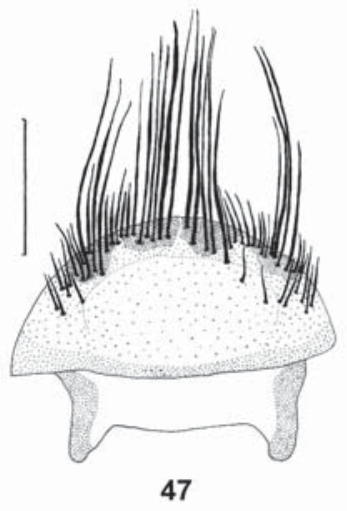

47

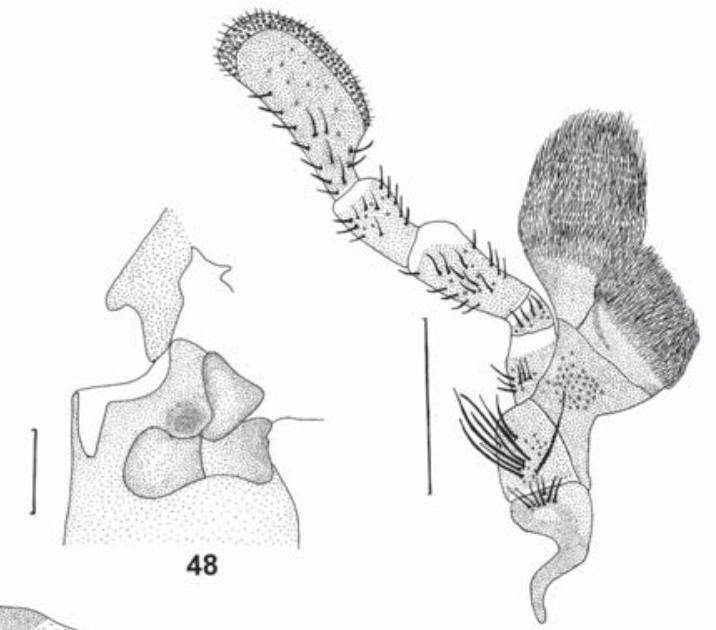

49
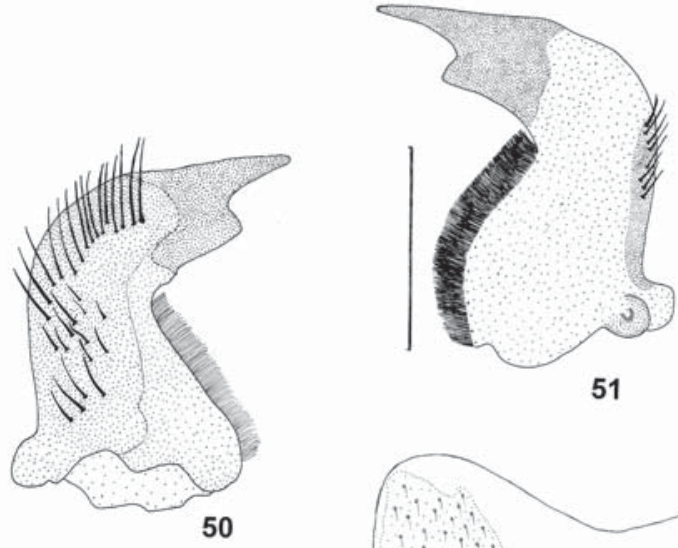

51
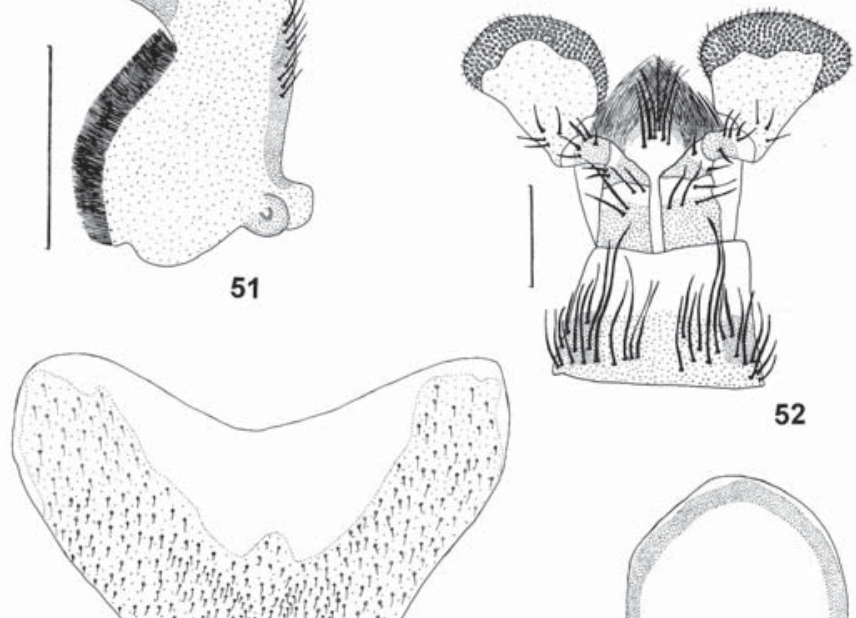

52
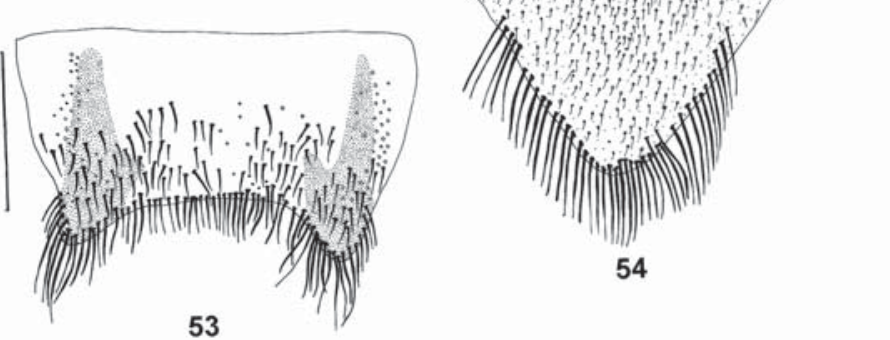

54

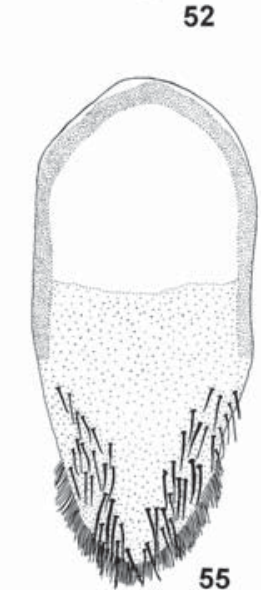

Figs. 46-55. Semiotus ligneus. 46, antenna; 47, labrum; 48, apex of prosternal spine and mesosternum (lateral); 49, maxilla; 50, 51, mandible (dorsal, ventral); 52, labium. Male: 53, sternite 8; 54, tergite 8; 55, sternite 9 . Bars, $1 \mathrm{~mm}$.

setae laterally near apex. Sternite 8 (fig. 61) elliptical, clothed with short setae; longer setae near margin; spiculum gastrale very long, 4.7 times sternite length. Genitalia (fig. 59): ovipositor with stylus; bacula 7 times coxites length; each opening of colleterial gland with one sclerotized wing-shaped plate, with 7 rows of teeth innerly; bursa copulatrix bearing small spines at middle; two spermathecae distally.

Material examined. MEXICO, Veracruz: Dos Amates (cerca Catemaco), ơ. PANAMA, Canal Zone: Barro Colorado 4 §, 7 ६; (Biol. Station), 4 ॐ. COLOMBIA, Valle: §. FRENCH GUIANA, Montagnes Tortue, f. BRAZIL, Amazonas: Benjamin Constant (Rio Javari), 2 o, 84 §; Iguarapé Gurupi-Una (Aldeia Araçu MA $50 \mathrm{Km}$ E. Canindé), §; Itacoatiara, 6 ‡; Lago Pantalgão
(Rio Japurá), §; Rio Juruá, §; Tabatinga, 3 ; Tefé, §; São Paulo de Olivença (Rio Solimões), 5 \&; Roraima: "Posto Indígena" 7 de Setembro, 2 ¡; Pará: Itaituba (Rio Tapajoz), 5 \&; Óbidos, 7 \%; (Santarensinho, Rio Tapajós), 12 §; Acre: Alto Purus, 4 §; Mato Grosso: Porto Velho (Rio Tapirapé); Rosário, ł; São Paulo: Instituto Oswaldo Cruz, Zona NOB Salobra, 3 đ; São Paulo (Ipiranga), †; Paraná: Rolândia, ঙ. PERU. Loreto: Pucallpa (Rio Ucayali), ક. BOLIVIA, Cochabamba: Chapare $3 \%$; (Villa Tunari), 2 ; El Carmen, o; Santa Cruz: Gutierrez, or. ARGENTINA, Salta: Aortagal, 2 o; S. Martin Politos, ơ.

Remarks. Comparing the studied species it was observed that $S$. distinctus is similar to $S$. intermedius in coloration, but the latter presents fore angles of frons toothed and two longitudinal stripes on pronotum. In both species the last ventrite of female presents two elliptical fossae clothed with short setae and palpiger 

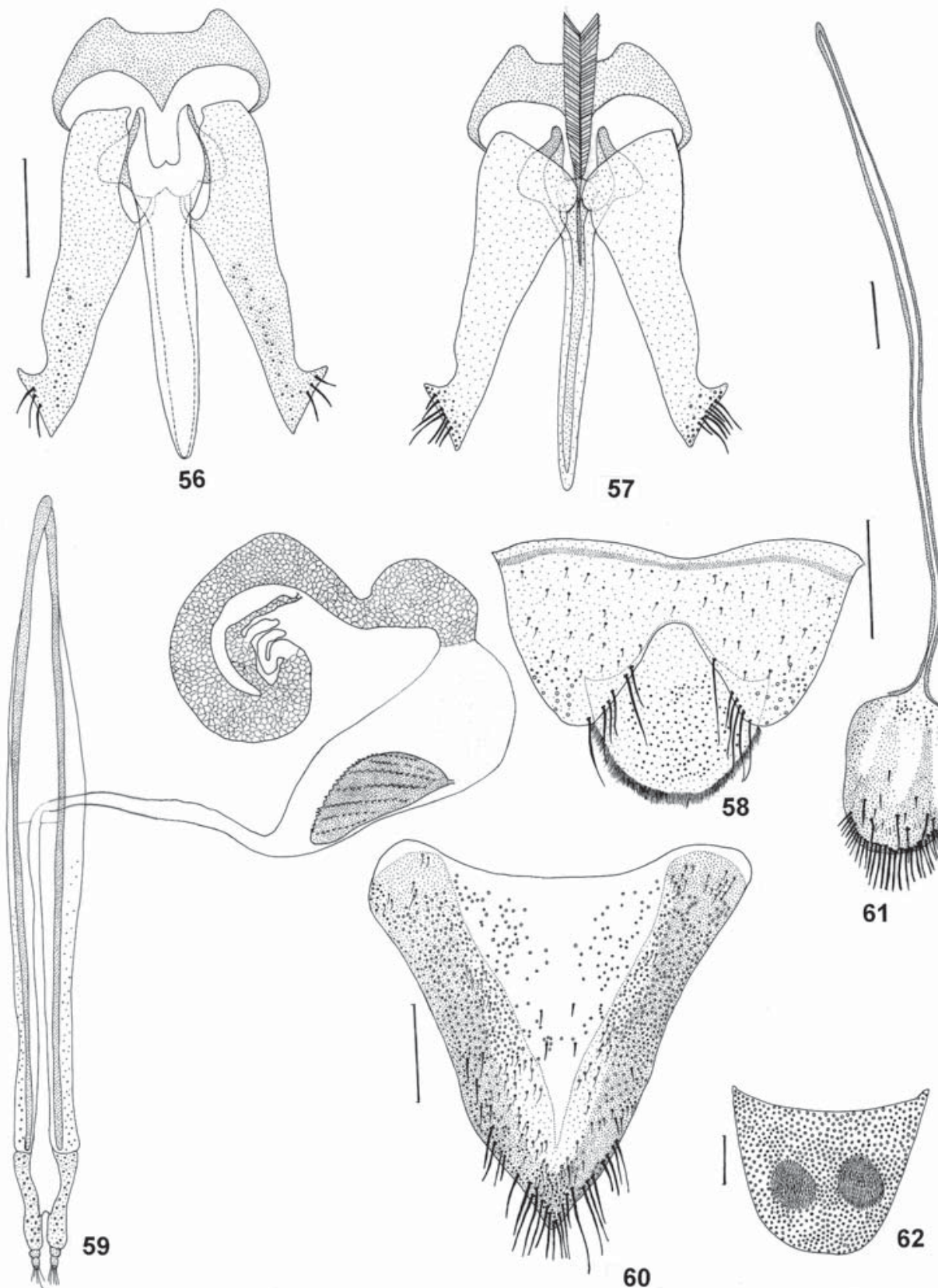

Figs. 56-62. Semiotus ligneus. Male: 56, 57, aedeagus (dorsal, ventral); 58, tergites 9-10. Female: 59, genitalia; 60, tergite 8; 61, sternite 8; 62, last ventrite. Bars $=1 \mathrm{~mm}$.

bearing 5 setae. S. distinctus differs from S. ligneus in coloration, but both species present the following characters: antennae of male longer than hind angles of pronotum, labrum semicircular, last article of labial and maxillar palpi strongly securiform, prosternal spine bilobed at apex and parameres of aedeagus with subapical lateral unciform tooth. S. intermedius is similar to $S$. ligneus specially by: anterior margin of sternite 8 of female widely notched and spiculum gastrale 4.7 times sternite length.

Candèze (1857) included $S$. distinctus and $S$. intermedius in different groups, based specially on the presence or absence of teeth at anterior margin of frons. $S$. distinctus and S. ligneus were included in the same group.
Semiotus distinctus is characterized specially by anterior margin of sternite 8 of female strongly notched and spiculum gastrale 4 times the sternite length; $S$. intermedius, frons with two anterior teeth, labrum subrectangular, basal piece of parameres long and bursa copulatrix with anchora-like sclerotized piece, and $S$. ligneus, palpiger bearing 4 setae and last ventrite of female with two rounded fossae clothed with short setae.

Based on the studied material, it was verified that S. ligneus presents a wider geographical distribution, being recorded from Mexico, Panama, Colombia, French Guiana, Brazil, Peru, Bolivia and Argentina, while $S$. distinctus is recorded from Brazil, Argentina and Paraguay and S. intermedius is restricted to Brazil. 
Acknowledgment. To Guilherme Ide Marques dos Santos (MZSP) by taking the pictures; to Fundação de Amparo à Pesquisa do Estado de São Paulo (FAPESP) by grant (IC 99/00317-5).

\section{REFERENCES}

BECKER, E. C. 1956. Revision of the Nearctic species of Agriotes (Coleoptera: Elateridae). Canadian Entomologist, Ottawa, 86(Supl. 1):1-101.

BLACKWELDER, R. E. 1944. Checklist of coleopterous insects of Mexico, Central America, the West Indies and South America. Bulletin of United States National Museum, Washington, 185(2):280-303.

Calder, A. A. 1996. Click beetles. Genera of the Australian Elateridae (Coleoptera). Monographs on invertebrate taxonomy. Victoria, CSIRO. v.2, 401p.

Calder, A. A.; Lawrence, J. F. \& Trueman, J. W. H. 1993. Austrelater, gen. nov. (Coleoptera: Elateridae), with description of the larva and comments on Elateridae relationships. Invertebrate Taxonomy, Canberra, 7:1349-1394.

CAndèze, E. 1857. Monographie des élatérides. Tome premier. Mémoires de la Societé Royale de Sciences de Liège, Liège, 12:1-400, 7pls.

— 1874. Révision de la monographie des Élatérides. Mémoires de la Societé Royale de Sciences de Liège, Liège, 4(ser. 2):1-218.

. 1891. Catalogue méthodique des élatérides connus en 1890. Liège, H. Vaillant-Carmanne. 246p.

CASARI-Chen, S. A. 1993. Systematics and evolution of Hemirhipini from Old World and Australia. I. Genera removed from tribe (Coleoptera, Elateridae, Pyrophorinae). Revista Brasileira de Entomologia, São Paulo, 37(2):223-262.

1994. Systematics and evolution of Hemirhipini from Old
World and Australia. II. Phylogeny of the tribe including the American genera (Coleoptera, Elateridae, Pyrophorinae). Revista Brasileira de Entomologia, São Paulo, 38(1):161252.

Castelnau, F. L. N. C. Laporte Comte De. 1840. Histoire naturelle des animaux articulés. Paris, v.1, 324p.

Снамpion, G. C. 1894. Biologia Centrali-Americana, Insecta, Coleoptera (Elateridae). London, British Museum (Natural History). v.3, p.258-296.

Eschscholtz, J. F. 1829. Elaterites, Eintheilung derselben in Gattungen. Entomologisches Archiv, Jena, 2:31-35.

Fabricius, J. C. 1792. Entomologia systematica. Hafniae. v. 1, 330 $+538 \mathrm{p}$

. 1801. Systema eleutheratorum. Kiliae. v.1, 506p.

GERMAR, E. F. 1839. Ueber die Elateriden mit häutigen Anhängen der Tarsenglieder. Zeitschrift der Entomologie, Leipzig, 1(2):193236.

Herbst, J. F. W. 1806. Natursystem .... Berlin. 285p.

Heyne, A. \& Taschenberg, O. 1908. Die exotischen Käfer in wort und bilt, 27 Lieferungen. Leipzing. 262p., $39 \mathrm{pl}$.

KIRBY, W. 1818. A century of insects, including several new genera described from his cabinet. Transactions of Linnean Society of London, London, 12:375-453.

LACORDAiRe, J. T. 1857. Genera des Colèoptères.... Paris, Librairie Encyclopédique de Roret. v.4, 579p.

Linnaeus, C. 1767. Systema natura. 12.ed. reformata. Holmiae. v.1, pars 2, p.533-1327.

Olivier, A. G. 1790. Entomologie... Coléoptères. Paris, v.2.

Schenkling, S. 1925. Elateridae I. Pars 80. In: Coleopterorum Catalogus auspiciis et auxilio W. Junk. Berlin, W. Junk. 263p. 